\title{
VELÜNK ÉLŐ AFRIKAI TÖRTÉNELEM...
}

\author{
TARRÓSY ISTVÁN
}

...csak mit sem tudunk róla, vagy csupán nagyon keveset, de bizonnyal nem eleget. Vajon miért? Talán, mert soha nem volt olyan fontos, érdekes, hasznos... számunkra (sem). Miért kellene tudnunk, ismernünk az afrikai térségek népcsoportjait, az ő történelmüket, történéseiket, azokat a folyamatokat, amelyek öket is, de amúgy minket is elértek? Oly távoli tájak tölünk oly különböző emberei, gondolhatjuk... De hiszen éppen azért lehetne, kellene többet és jobban tudjunk róluk, velük kapcsolatban, mert voltak, vannak és egyre inkább lesznek olyan folyamatok, események, amelyek őket is, minket is elérnek. Mára egy kikerülhetetlenül globális térben találjuk a nemzetközi rendszer valamennyi szereplöjét: az állami, nem állami szereplöket, és egyre inkább azon transznacionális tételeket, amelyek az állam felett, éppen a globális tér és hálózatok adta lehetőségeket használják ki, valójában ezek keltik öket életre, adnak nekik terepet a ténykedésre. Gondoljunk csak a világ akármelyik szegletében fel-felbukkanó terroristákra, avagy az emberiség kezdete óta létező migrációra, mely korunk egyik kézzel fogható valós globalitása. Ha más nem (pedig sok egyéb valóságmorzsa felsorolható lenne), akkor éppen a nemzetközi migráció az, ami miatt érdemes, fontos, igenis lényeges (jobban) megismernünk az afrikai kontinens történelmét. Azt bizonnyal jól tudjuk, hogy a Szahara - 7,8 millió négyzetkilóméterével Földünk legnagyobb kiterjedésủ sivatagja - földrajzi, kulturális, nyelvi, vallási törésvonal Afrikában: a tőle északra elterülő régió történelme szorosan egybefonódott Európáéval, a közös mediterrán térség „mindkét oldal” számára stratégiai jelentőséggel bír - akár a jelenleg is zajló (fel)fokozott migráció miatt. Mi a helyzet azonban a Szaharától délre elterülő területekkel, a szubszaharai Afrikával? Búr Gábor, Magyarország vezető Afrika-történészének könyve felettébb olvasmányosan tárja elénk e makró régió történelmét.

A Kossuth Kiadó által megjelentetett 20. századi világtörténelem-sorozat (A rövid XX. század címet viselö) 2011-ben kiadott kötete fontos referenciamunka 2021-ben is mindannyiunk számára. A szubszaharai Afrika története 1914-1991 ugyanis, ahogyan szerzője már a Bevezetésben jelzi: az „általános ismertetés mellett néhány kiválasztott »száliránnyal szembeni« feldolgozás[ával] kívánja az olvasó számára a kontinens [e részének] történelmét közelebb hozni.” (11. o.) Búr Gábor hét fejezetben tekint át több fontos időszak megannyi afrikai eseményét, szereplöjét, hol országokra helyezve a fókuszt - kvázi rövid esettanulmányok formájában -, hol 


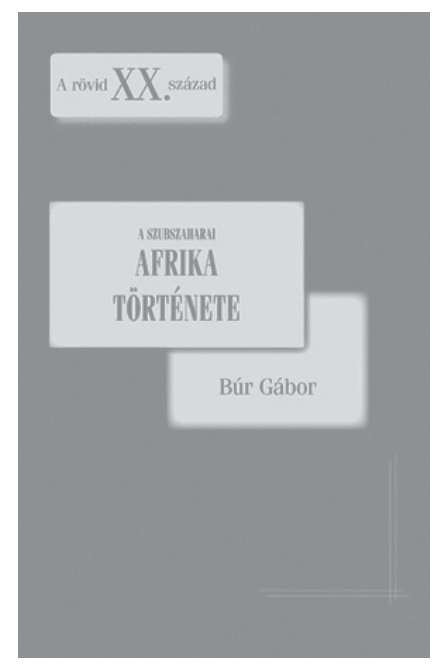

\section{Búr Gábor}

\section{A szubszaharai Afrika története 1914-1991}

Budapest, Kossuth Kiadó, 2011

mérvadó afrikai vezetők és történelmi nagyságaik lényegi összefoglalását ajánlva az olvasó figyelmébe. II. Menelik, Kwame Nkrumah és Nelson Mandela is terítékre kerülnek, mindvégig értelemszerüen azon afrikai függetlenedési törekvések és tettek fényében, amelyek a mai Etiópia, Ghána és Dél-afrikai Köztársaság számára is példaértékünek bizonyulnak. II. Menelik 1896. március 1-jén képes volt megverni Aduánál Olaszországot, ,amely nem csupán taktikai, hanem stratégiai vereséget is szenvedett" (22. o.) ezáltal. Jogosan emeli ki a szerzö, amit a mai napig minden büszke etióp alapértékként kezel, azaz, hogy a 19. század végi Abesszínia „minden afrikai és afroamerikai szemében az alávetés elleni sikeres küzdelem szimbólumává vált." (uo.) Az egyik igazán ikonikus afrikai szabadsághős és szimbólum, Nkrumah, nagy reményekkel vágott neki az 1957. március közepén Aranypartból lett független Ghána építéséhez, de rövid időn belül, ahogyan Búr jelzi, „terveinek megvalósításához egyre inkább diktatórikus eszközökhöz folyamodott. [...] Ahogy [pedig] Nkrumahon elhatalmasodott a paranoia [...] miniszterelnökből először választott, majd 1961-től örökös államfővé vált." (124-125. o.) Nelson Mandela nem csupán a „dél-afrikai »tárgyalásos forradalom《 valódi hőse” (197. o.) volt, hanem egyúttal az egész békés rendszerváltás otthon és külföldön egyaránt tisztelt jelképe. Ahogyan pedig Búr nyomatékosítja, e rendszerváltás éppen emiatt bír történelmi jelentőséggel, „éles kontrasztban a kontinens tucatnyinál is több kudarcos államával szemben.” (200. o.)

Miután a szerző alaposan áttekinti Afrika gyarmati felosztásának főbb mozzanatait (1. fejezet), ezzel a könyv címében jelzett időszak előzményeit megfelelően kontextualizálja, három fejezeten keresztül taglalja Afrika helyét, szerepét és a területén lezajlott történéseket, illetve azok következményeit az első és második világháborúban, valamint az ún. gyarmati béke korának éveiben. Látnunk kell, amit Búr ki is emel, hogy az első világháború alatt a „gyarmatok kérdése 
mindvégig napirenden maradt, [...] a németek bármiféle kiegyezés előfeltételeként szabták meg területeik visszaadását, sőt azok bővítését a belga és a portugál birtokokkal is, s ez hozzájárult a világégés alatti békepuhatolódzások zátonyra futásához." (38. o.) Azon paternalista európai hozzáállás, amely sok esetben időnként még ma is felfelbukkan egészen biztosan visszavezethető a 19. század végi, 20. század eleji felsőbbrendủ európai vélekedésekig, mely nem volt „hajlandó elfogadni, hogy Afrika bármilyen értékek létrehozója lehet. [...] a gyarmatok alsórendủ népességét csakis felsőrendủ európaiak igazgathatták [megfelelően]." (46-47. o.) Mindezeket könnyedén volt képes alátámasztani mind a Lugard-féle, mind a Sarraut-féle brit és francia uralmi modell, merítve a kor szociáldarwinizmusából, amely végig táplálta azt az európai meggyőződést, „hogy csak külső beavatkozás révén indulhat meg Afrikában a társadalmi fejlődés, amelyhez Európának kell segédkezet nyújtania.” (51. o.) Az afrikai oldalon egyre terebélyesedő pánafrikanizmus azonban fontos kapaszkodót kínált az afrikai öntudat felerősödésének - úgy az angolszász vonal az USA-ban élő William Du Bois vezényletével, mint a frankofón négritude irányzat Aimé Césaire szellemi iránymutatásával. A négritude pontosan fogalmazta meg, hogy ,az afrikaiak külön társadalmi, politikai lények, [...] olyan intézmények kiépítésének [igényével], amely megfelel sajátos szükségleteiknek." (55-56. o.) A gyarmati béke éveit követően Afrika újból világháborús hadszíntérré (ugyan mellékhadszíntérré) vált, és ez világosan jelezte a kontinens stratégiai felértékelődését (83. o.)

Az ötödik fejezet az afrikai dekolonizációs folyamatot fogja össze 1945 és 1960 között. Szó esik az ENSZ és Afrika kapcsolatáról, az ún. gyámsági területekről, Afrika infrastrukturális bekötöttségének és elérhetőségének javitásáról (pl. a megsokasodott repülőjáratokról, 96. o.), az első függetlenné váló államokról (ld. Ghána, 99-104. o.), de még inkább részletesen az egyes gyarmatosító hatalmak hozzáállásáról a függetlenségi törekvéseket illetően. A hatodik fejezet a hidegháború korszakában (1960 és 1991 között) vizsgálja Afrika történelmét. A gyarmati igát magukról lerúgó afrikai területek újdonsült helyi vezetői által végrehajtott afrikanizáció (127-132. o.) látványos eszköze volt a „szakításnak”. Az „állami vagy közszolgálat afrikanizálása sehol sem volt [azonban] egyszerü feladat” (128. o.), hiszen kevés volt a (jól) képzett afrikai, aki a kormányzást minőségi módon tudta átvenni a volt európai gyarmatosítóktól. Ahogyan Búr Gábor fogalmaz, e bő három évtized alatt 
„sajátságos nagyhatalmi munkamegosztás érvényesült Afrikában” (141. o.), és a volt gyarmatosítók befolyása egyértelmúen megmaradt, máig ható - de persze változó mértékben tetten érhető - módon fennmaradt. Fontos rész a könyvben az etnikai konfliktusok tárgyaló rész (144. oldaltól), amely segíthet jobban megértenünk a 2021-ben (még mindig, vagy éppen újból) zajló afrikai krízishelyzeteket, így például az etiópiai, a dél-szudáni, valamint a szomáliai konfliktusokat, de ugyanúgy a mai kenyai, angolai, mozambiki, illetve zimbabwei politikai helyzeteket, társadalmi állapotokat. Való igaz, hogy az „1990-es évek elejére Afrika a nagyhatalmak gazdasági és geostratégiai érdeklődésében elvesztette korábbi jelentőségét" (188. o.), melyek hátterében markánsan ott találjuk a Szovjetunió felbomlását, a bipoláris világ megszünését, a kelet-közép-európai rendszerváltásokat. A rövid 20. század végén azonban egy újabb fordulatot hozott a dél-afrikai apartheid felszámolása, melyről a szerző talán a legkiterjedtebb tudástárral rendelkezik hazánkban. A hetedik fejezetet éppen e témának szenteli, hangsúlyt helyezve arra, hogy a poszt-apartheid időszak Dél-Afrikája „,a kiútkeresésnek, az »afrikai tragédia« meghaladásának motorjává vált." (200. o.)

Búr Gábor könyvét egyértelmüen ajánlom kutatóknak, nemzetközi stúdiumokat oktató kollégáknak, Afrika-kurzusokat hallgató egyetemistáknak ugyanúgy, mint leendő afrikai diplomatáinknak, a gazdasági élet szereplőinek és a civil szektorban Afrikával foglalkozóknak, Afrikában tevékenykedőknek. Valójában mindenkinek, akit egyfelől érdekel Afrika múltja, jelene és lehetséges jövője, másfelől tenni akar Afrikáért, Afrikában és természetesen Afrikával együtt közösen. A kötet segíthet abban, hogy többet tudjunk Afrikáról, jobban értsük az Afrikával kapcsolatos történéseket, amelyek világos módon minket is érinthetnek.

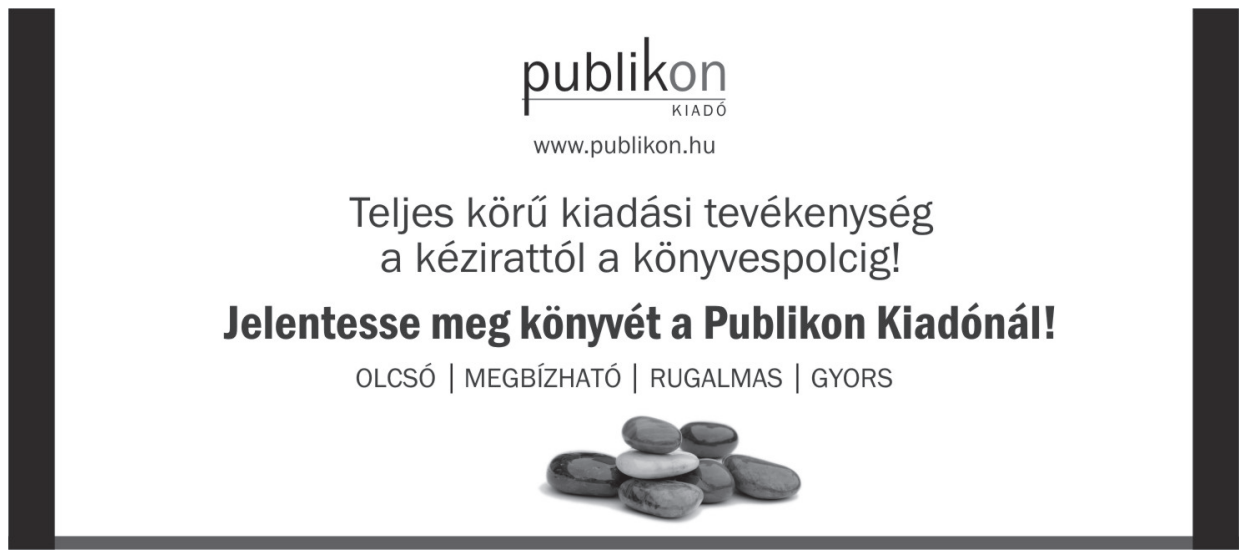

